\title{
POST-EDUCATION EVALUATION AND LEADERSHIP TRAINING NEW LEVEL II LEADERSHIP TRAINING DESIGN: A STUDY AT CENTER FOR STUDY, EDUCATION, AND TRAINING OF APPARATUS III STATE ADMINISTRATION INSTITUTE OF SAMARINDA/PKP2A III LAN SAMARINDA
}

\author{
Annisari Atika*, Gani Abdul Juli Andi, Setyowati Endah \\ Master's Program of Public Administration, Faculty of Administrative Science, Universitas \\ Brawijaya, Indonesia \\ *Email: atika.annisari@gmail.com
}

\begin{abstract}
Post-Education Evaluation and New Level II Leadership Training Designs for alumni held by the Center for the Study and Education and Training of Apparatus III The State Administration Institute (PKP2A III LAN) aims to describe and analyze the application of training results on the improvement of competence and performance of alumni and factors the factors affecting it. This research method used a qualitative approach, with research sites on PKP2A III LAN and alumni institution of origin in Samarinda. The research focuses on the application of alumni education and training outcomes which include aspects of participant characteristics, training design, work environment, alumni utilization in positions, and the impact of training on alumni performance and competence, and focus on supporting factors and inhibiting the implementation of training results. Using interactive data analysis by Miles, Huberman, and Saldana. The result is the application of the training result is very influential on the improvement of the competence and the performance of training alumni, where the support of the policy, leadership commitment, mentor, staff, facilities and infrastructure and stakeholder become the supporting factor, while the constraining factor is the budget limitation. Diklatpim innovative projects have high benefits characterized by positive responses from the community, increased public service satisfaction, and performance apparatus and organization is increasing.
\end{abstract}

\section{KEY WORDS}

Post-training evaluation, leadership training, new design, performance, competence.

Education and training (diklat) for the State Civil Apparatus (ASN) is part of ASN management to improve government agencies apparatus performance and competence, especially for ASNs who occupy structural positions in government organizations. As stated in Law No. 5 of 2014 on ASN, the Leadership Training (Diklatpim) is conducted to prepare ASNs for managerial positions, such as Position of High Leader (Echelon II), Administrator's Position (Echelon III) and Supervisory Office (Echelon IV).

In the personnel management system, the echelon II structural officer (at director's level, head of agency, agency, or central) plays a decisive role in defining the agency's strategic policy, leading subordinates and all strategic stakeholders to implement the policy effectively and efficiently.

Implementation of Diklatpim New Level II Leadership Training as stipulated in Regulation of Head of LAN Number 18 the Year 2015 on Guidelines of Education and Leadership Training Level II Implementation. The training not only equips participants with the required competencies to be strategic leaders, but also the capability to apply possessed competencies. Participants are required to demonstrate their performance in designing an innovation in their work units and lead to produce significant results. The ability to lead this innovation then determines the success of the participants.

Leadership training new design formed by LAN is also called as a reformation of the training system. The focus on this New Design is the formation of professional bureaucrats who are able to internalize the basic values of ASN and high ethical public order. Significant changes include on learning materials designed to enhance bureaucratic leadership skills in the public sector in the endeavor to lead change process in respective institutions. 
The previous diklatpim only focuses on the ability to develop action plans, classes are theory-heavy than practice, and too much material related to managerial techniques. Traning New Design not only nurtures the ability to develop an action plan but also the ability to implement, more practice and emphasis on leadership character formation, ability to complete and implement innovative projects in the organization according to their respective duty, and adaptability to innovative values.

In terms of implementation, the New Level II Leadership Training takes a longer time compared to previous designs, as it takes four months instead of 70 days. Learning materials are on-off campus experience-based. On Campus, stages are done by learning method in the class, visitation to a destination related to education and activity on enriching innovative project through Benchmarking. The Off-Campus stage includes the first breakthrough step in which the participants are expected to be able to draw up an innovative project proposal and have it approved along with the direct supervisors of the participants. The second breakthrough step is the stage of implementation of the innovative project.

Previous training participants only produce Individual Working Document (KKP) documents, while the new training requires the participant to make an innovation project related to their daily duties and functions. During the design process up to the implementation of the innovative project, it is imperative that the training participants be able to influence the people involved in the organization to implement innovative projects.

Implementation of Level II Leadership Training is an obligation for Senior Officials in Indonesian government agencies, where PKP2A III LAN as part of the State Administration Institution is an institution granted authority to conduct Level II Leadership Training. 119 alumni of Level II Leadership Training Design has produced innovative projects from 2015 to 2016. There's wide alumni distribution both from the local government agencies and the central based inside and outside Kalimantan.

In order to achieve the determined objective, diklatpim conducted evaluation activities at the end of learning and post-diklatpim evaluation. Evaluation is part of efforts to strengthen and improve the implementation of the training, especially in the implementation phase of post-training evaluation.

Post-Training Evaluation is used to assess the outcomes of objectively planned outcomes, therefore the success and effectiveness of a training can be determined. This result is a feedback to plan future training and make a positive contribution to the improvement of training participants alumni.

This research is based on the importance of the role of post-leadership training evaluation of new level II leadership as a basis for change or improvement of the training program. This New Design of postdoctoral leadership evaluation study of the New Design shows how much of the utilization of the new level II training of PKP2A III LAN in relation to the improvement of competence and performance of alumni and the factors that influence the application of Level II Leadership Training.

\section{LITERATURE RIVIEW}

The research is based on a Journal by Timothy T. Baldwin and J. Kevin Ford (1988) entitled Transfer of training: a review and directions for future research. Baldwin and Ford argue that the concept of the transfer of training results refers to the extent to which the training alumni are able to effectively and continuously apply the competencies (knowledge, skills, and attitudes) that they acquire during training in their duties.

Baldwin and Ford developed a training transfer model, in which the transfer of training results is influenced by input, output, and transfer conditions. The training input aspect is a condition in which the various factors before the training that affect the learning process in the training will then determine the outcome/output of the training. These factors are the characteristics of the participants, the training design, and the work environment.

Characteristics of the training participants are ability, personality, and motivation which will support the process training result transfer. The second factor is the training design, covering training materials, methods, classrooms, instructors, and organizing process. A third factor is the work environment where the support within the organization will be felt by the 
employee when they believe that their leader and workgroup provide opportunities to practice new knowledge and skills in the workplace. The opportunity to practice the results of the training would encourage process or learning culture, therefore, participants would be able to apply obtained knowledge in their work.

According to Purwanto in Suparman (2010), evaluation is one of the links in the training system implemented from the beginning of the planning process, the implementation process, at the end of the implementation of the training until after the training participants are in the workplace.

Evaluation can be grouped into two types: 1) evaluation to assess the success of a learning, and 2) evaluation to assess the success of a particular program. Evaluation of learning outcomes assesses participants' mastery of the taught material, whereas program evaluation assesses the extent to which the program is beneficial or has an impact on organizational performance.

In the context of the evaluation of the training program, the focus of evaluation is directed to assess two things: 1) evaluation of training implementation and 2) evaluation of the impact or benefits of the training. This type of evaluation of the training impact is known as post-training evaluation. This post-training evaluation is also called the concept of training outcome transfer, defined as the extent to which the trainees apply the knowledge, skills, and behaviors learned in the training at their workplaces

\section{METHODS OF RESEARCH}

This research uses a qualitative approach. Source of data used were informants, documents, and events. The research informants came from PKP2A III LAN and 10 (ten) alumni of Level II Leadership Training in Samarinda. While the document used in the form: No. 18 the Year 2015, Renstra PKP2A III LAN, publication, the result of the report of the diklatpim level II second level year 2015 and result of the report of diklatpim level II the year 2016. The event is the process of innovative implementation in alumni of leadership training projects at their respective organization.

\section{RESULTS AND DISCUSSION}

The Center for the Study, Education, and Training of Apparatus III of the State Administration Institution (PKP2A III LAN) is located in Capital of East Kalimantan Province Samarinda. It is the only implementing institution of the second level Diklatpim which is mandated by the State Administration Institution to organize Diklatpim New Design in Kalimantan region. From 2015 to 2016, PKP2A III LAN has organized two new level II leadership training courses, in which the training participants are not only from Borneo but are from all regions of Indonesia. Implementation of Level II Leadership Training has been referred to the Regulation of Head of LAN no. 18 years 2015.

Based on the focus of research, post-diklatpim evaluation of the Level II Leadership Training is exhibited in the form of application of alumni training results. This can be analyzed from five aspects: (a) characteristics of training participants; (b) design of training; (c) the working environment; (d) utilization of training alumni in the position; and (e) the impact of leadership training on improving the performance and competence of alumni.

Characteristics of participants that includes the ability, personality, and motivation that exist within the participants are very supportive of the process of transferring the training result, which is obtained from the activities during the training. According to Ron Kurtus in Soedarsono (2005), the character is a set of behavior or behavior of a person. Characteristics of the training participants are aspects or qualities of the training participants consisting of interest, attitude, motivation to learn, learning style, ability to think and the initial ability it has, which then through the training will change behavior.

Behavior change is intended as a result and consequence of participant participation in Training as well as a form of success in the following training. Assessment of the application of behaviors acquired during training focuses on values of integrity, public ethics, discipline, and cooperation. These four values become part of the assessment of the results of the 
training. The change of behavior is more meaningful because it can be useful and support the implementation of the task of participants in their respective institutions, especially in improving creativity and work motivation, supporting the certainty of the acceleration of activities, the accuracy of the activities objectives, and the results of activities.

Training design in the form of training program includes the taught material, learning method used, teachers, and the instructional media applied. In other words, the training design includes training materials, methods, classrooms, instructors, and organizing process. The better the training design, the more likely the transfer of training results. The structure of the Level II Leadership Training curriculum is organized into five stages of learning: (1) Innovative Need Diagnostic Phase; (2) Taking Ownership Phase (Breakthrough I); (3) Designing Innovative Program and Team Building; (4) Stage of Leadership Laboratory (Breakthrough II); (5) Evaluation Phase, which is the stage of sharing knowledge and experience in leading the implementation of change projects. The activities are conducted in the form of seminars.

The training materials were handed over to facilitators and Widyaiswara. LAN has set up training modules, so the development of training materials should lead to the achievement of training goals, curricular goals, and instructional goals. The instructional objectives lead to the expectations and needs of the institution to the competencies to be achieved. According to Atwi-Suparman (2012: 283), there are three kinds of instructional activities that resulted in three forms of instructional materials. Firstly, teaching as facilitators and learners is selfdirected by using specially designed self-directed instructional materials. Second, the instructor as teaching material provider uses a compilation of instructional material. Third, the teacher as facilitator uses a combination of two forms of instructional materials i.e selfinstructional materials and compilation materials.

The transfer of learning to the training result is influenced by three main factors, namely; ability to use, motivation to use, and the work environment (Blanchad \& Thacker, 2007). The ability of participants to apply learning is taken into account: the capacity of participants to make changes, work situations provide opportunities to apply learning outcomes, relevant learning outcomes, thoughts to be applied. Motivation involves confidence in applying new skills to improve performance, as well as rewarding the application of new skills and values. Another thing that affects motivation is the participants' confidence and readiness to participate in the training. The work environment includes the influence of superiors, working groups, and reward systems.

The work environment strongly supports the transfer of training outcomes, where the support within the organization is felt by the alumni when they believe that others (such as bosses, working groups) provide opportunities to practice new knowledge and skills in the workplace. There is an opportunity to practice the results of the training and learning process or learning culture so that what they have learned can be applied to their work.

Utilization of alumni of Leadership Training in the position or in other words the application of skills in the workplace after the training is seen from leadership skills, especially in making changes to the work unit. Skills acquired during the training have been applied to the work unit, such as coordination skills, communication, and building a solid and effective team.

The results of the training play a role in improving the quality of professional apparatus resources with competence, attitude, and behavior. Sudjana (2009: 22) explains that the learning outcomes as the ability of the participants of the training after receiving the learning experience. Post-training Evaluation of new level II leadership training on PKP2A III LAN indicates that this training has succeeded in creating innovative and high performing change leaders.

There are factors that support the implementation of post-training alumni programs after participating in new level II leadership training held by PKP2A III LAN Samarinda, those are policy support, leadership commitment, mentor, staff, facilities and infrastructure, and stakeholders. All of the supporting factors indicate that this training activity is very important in the effort to support the creation of good governance and professional government. While the inhibiting factors are budget constraints. Diklat alumni which incidentally is posted as head of the department based their Work Plan Budget on the institution they were posted in 
prior to joining the training program, therefore the result of learning which will be applied in the form of an innovation project is hampered due to budget factor.

Implementation of the post-leadership training alumni innovative projects should remain sustainable. This can be done through putting into planning the next year's agency activities; conduct intensive coordination and communication with stakeholders with monitoring and supervision of innovation projects; and formulate into regional regulations or service standards related to public services so as to create a more professional, effective and excellent future bureaucracy.

\section{CONCLUSION}

There are significant application of training result which has an effect on to Diklatpim alumni competence and performance improvement of New Level II Leadership Training organized by PKP2A III LAN, covering: (a) Characteristic of participant, training design and work environment obtained after following training support process transfer of training result ; (b) Most of the Diklatpim alumni are empowered in their positions while continuing with their innovative projects; (c) The new level II Leadership Training has succeeded in creating innovative and high performing innovative leaders. Supporting factors are the support policy, committed leaders, mentors, staff, facilities and infrastructure, and stakeholders. While the inhibiting factors are budget constraints.

Some suggestions that can be recommended in terms of the implementation of New Level II Leadership Training alumni result are as follows: (a) It is necessary to link the theme of the innovative project specifically to the problems in the local content of East Kalimantan, where local governments need to establish a policy that can safeguard the continuity of the project innovation; (b) Local governments need to make a roadmap of regional innovation, therefore, leadership training participants can adapt to the needs of their local innovation roadmap.

In relation to the supporting factors and obstacles to the implementation of alumni training result after the Level II Leadership Training, it is recommended that: (a) LAN and related institutions create an integrated monitoring and evaluation system to guard the sustainability of the implementation of the post-training innovative project; and (b) The need for leadership commitments embodied in the work contract prior to the training to minimize the inhibiting factors so that the implementation of the training results in the form of a change project is sustainable.

\section{REFERENCES}

1. Atwi, S, M. (2012). Desain Intruksional Modern: Panduan Para Pengajar dan Inovator Pendidikan. Jakarta: Erlangga

2. Blanchad, P. Nick., \& James W. T. (2007) Effective Training: Systems, Strategies, and Practices $\left(3^{\text {rd }} \mathrm{Ed}\right)$. New Jersey: Pearson Prentice Hall.

3. Blume, B. D., Ford, J. K., Baldwin, T. T., \& Huang, J. L. (2010). Transfer of training: A meta-analytic review. Journal of Management, 36(4), 1065-1105.

4. Miles, M. B., Huberman, A., Michael., Saldana, J. (2014). Qualitative Data Analysis, A Method Sourcebook (3rd Ed). New York: SAGE Publication.

5. Peraturan Kepala LAN Nomor 18 Tahun 2015 tentang Pedoman Penyelenggaraan Diklatpim Tingkat II.

6. Soedarsono, S. (2005). Hasrat untuk Berubah. Jakarta: PT Elex Media Komputindo.

7. Sudjana, N. (2009). Penilaian Hasil Proses Belajar Mengajar. Bandung: PT Remaja Rosdakarya.

8. Suparman, R. (2010). Evaluasi Pasca Diklatpim Tk.IV. Bandung: PKP2A I LAN.

9. Undang-Undang Republik Indonesia No. 5 Tahun 2014 tentang Aparatur Sipil Negara. 